\title{
Efficiency of Pollution Tolerance Index (PTI) of macroinvertebrates in detecting aquatic pollution in an oxbow lake in India
}

\author{
Dipankar Ghosh ${ }^{1}$ Jayanta Kumar Biswas ${ }^{1,2, *}$
}

\section{Edited by \\ Juan Carlos Salcedo-Reyes \\ (salcedo.juan@javeriana.edu.co) \\ 1. Department of Ecological Studies, University of Kalyani, Kalyani, Nadia, West Bengal - 741235, India. \\ 2. International Centre for Ecological Engineering, University of Kalyani, Kalyani, Nadia, West Bengal - 741235, India. \\ * biswajoy2000@yahoo.com}

Received: 16-01-2017

Accepted: 25-10-2017

Published on line: 20-11-2017

Citation: Ghosh D, K Biswas J. Efficiency of Pollution Tolerance Index (PTI) of macroinvertebrates in detecting aquatic pollution in an oxbow lake in India, Universitas Scientiarrm,

22 (3): 237-261, 2017.

doi: 10.11144/Javeriana.SC22-2.eopt

Funding:

The authors acknowledge the support provided by the Department of Ecological Studies at the University of Kalyani; Department of Fisheries of the West Bengal Government, and the Kutirpara Fishermen Co-operative Society Ltd. of the Nakashipara Development Block, Nadia, West Bengal, India.

Electronic supplementary material: Suppl. 1-4.

OPEN ACCESS

\begin{abstract}
This paper evaluates the efficiency of a macroinvertebrate-based Pollution Tolerance Index (PTI) in detecting aquatic pollution in the Chhariganga oxbow lake in India. In this lake, calculated PTIs were compared with results from an array of physicochemical water and sediment parameters and to a macroinvertebrate diversity assessment conducted in parallel for the same lake. The obtained PTI values fell in a range (between 20 and 31) that are indicative of an absence of organic pollution according to the literature, and are normally reported for systems devoid of anthropogenic activity (for instance no monsoonal polluting jute retting activities). However, in the light of the results for the assessed water and sediment physicochemical parameters, and the support of diversity indexes of macroinvertebrates, using data from the same lake, it was possible to conclude that the obtained PTI values do not reflect the true pollution status of this oxbow lake. As PTI values and diversity indexes contradict each other in detecting pollution, it is advised to take both parameters into consideration when using macroinvertebrates to assess aquatic health.
\end{abstract}

Keywords: aquatic health; diversity indexes; macroinvertebrates; pollution; water quality

\section{Introduction}

Macroinvertebrates play an essential role in aquatic habitat food webs (Ziglio et al. 2006). Their high functional and taxonomic diversity, ubiquity, tolerance of wide environmental gradients, rapid, and often predictable response to environment changes of natural and anthropogenic origin make them useful bioindicators of aquatic health status (Rosenberg \& Resh, 1993; Bonada et al. 2006). Moreover, macroinvertebrates display a limited migration pattern (with low mobility and generally sessile or sedentary habits) 
facilitaing their collection and identification (Barbour et al. 1999; Ziglio et al. 2006). Macroinvertebrates also have long life spans (of several weeks to years), and are thus indicative of changing water qualities by reflecting cumulative effects of the present and past conditions of short- and long-term environmental stressors (EPA, 1998) which became important areas for maintaining biodiversity (Meyer et al. 2007; Richardson \& Danehy, 2007).

Macroinvertebrates have been widely used as bioindicators in impact studies of environmental perturbations on aquatic ecosystems (Lenat et al. 1981; Victor \& Ogbeibu, 1985; Ortiz \& Puig, 2007; Olomukoro \& Dirisu, 2014), water quality assessments (Sharma \& Rawat, 2009), and organic and inorganic pollution monitoring studies (Thorn \& Williams, 1997; Kazanci $\&$ Dugal, 2000). Macroinvertebrates are thus useful to understanding the ecological health of an aquatic ecosystem and can complement, and even become an alternative to, chemical and microbiological analyses, because they are sensitive to short-term fluctuations of the aquatic health (Ravera, 2000; Ikomi et al. 2005; George et al. 2009; Olomukoro \& Dirisu, 2014). Their community assemblages vary in time and space and their diversity within a certain area is related to water fertility and productivity (Latha $\&$ Thanga, 2010). Biomonitoring studies employing macroinvertebrates to rate the quality of both lotic and lentic water bodies have been widely reviewed (Ogbeibu \& Oribhabor, 2002; Clarke et al. 2003; Imoobe \& Ohiozebau, 2009; Omoigberale \& Ogbeibu, 2010; Birk et al. 2012 and Olomukoro \& Dirisu, 2012). The ecological assessment of aquatic systems with macroinvertebrates is one of the most frequently used protocols for water quality evaluations in standard water management. Furthermore, macroinvertebrate abundance, community structure, and ecological functions are broadly used to characterize water quality in freshwater ecosystems (Odiete, 1999).

In India, a limited number of studies have used aquatic macroinvertebrates in water quality bioassessment (Nandan, 1997; Balachandran \& Ramachandra, 2010; Latha \& Thanga, 2010; Alakananda et al. 2011; Balachandran et al. 2012; Gupta \& Narzary, 2013; Kumar \& Khan, 2013; Rashid \& Pandit, 2014; Doley \& Kalita, 2014), and only one has addressed the ecological aspects of macroinvertebrates in an oxbow lake (Chakrabarty \& Das, 2006). Nonetheless, the use of aquatic macroinvertebrates to rate the water quality of oxbow lakes in India remains poorly documented and macroinvertebrates, seasonal distribution in relation to physicochemical variables is neither well known in West Bengal oxbow lake ecosystems. 
In the present study, in order to evaluate water quality and aquatic health status through seasonal bioassessment in an Indian oxbow lake, a survey and analysis of the seasonal structure of lake macroinvertebrate communities was conducted. Further, the composition and physicochemical parameters of the lake were also assessed. The studied oxbow lake is part of the Ganga river basin in the Nadia district, West Bengal. The core of the macroinvertebrate assessment for this lake consisted of obtaining and analyzing the pollution tolerance index (PTI) as designed by Olomukoro \& Dirisu (2014). Thus, the present study is also an opportunity to test the efficiency of this approach in evaluating an Indian water system.

\section{Materials and methods}

\section{Study area}

The Chhariganga oxbow lake is located in Nakashipara development block of Nadia district, West Bengal, India $\left(23.5779214{ }^{\circ} \mathrm{N}, 88.3471226^{\circ} \mathrm{E}\right)$. This lake is situated at about $90 \mathrm{Km}$ away from Kalyani university campus, Nadia and nearly $40 \mathrm{~km}$ north of the tropic of cancer line. The Chhariganga oxbow lake was formed as an abandoned meander of the river Ganga and is a fresh water, semi-closed oxbow lake that receives water from the Ganga river, during monsoon, through a narrow channel at the north-east corner of a loop of the river. The Chhariganga oxbow lake also stores rain water. This oxbow lake is spread over an area of 58.28 ha with an annual average depth of $2.6 \mathrm{~m}$. The catchment area of the oxbow lake is nearly 600 ha (Fig. 1).

The oxbow lake was selected at random among a total of 122 similar oxbow lakes in Nadia District, West Bengal. There are three distinct annual seasons in this region: pre-monsoon or dry season, from March to June; monsoon, or rainy season, from July to October (within this period jute retting takes place, generally from August to September); and post-monsoon or winter season, from November to February. There have been occasional inundations of the surrounding banks during monsoon. The Chhariganga lake is subjected to all forms of human activities including jute retting during monsoon, agriculture and fishing. It is the only source of irrigation water to the immediate agriculture communities.

The Chhariganga oxbow lake has taken different names in four different development block locations like "Errerdanga Chhariganga", "New Chhariganga" along its largest (about $88.63 \mathrm{ha}$ ) segment in Kaliganj, "Bhagirathi Chhariganga" in Nabadwip, "Chhariganga" in Nakashipara and 


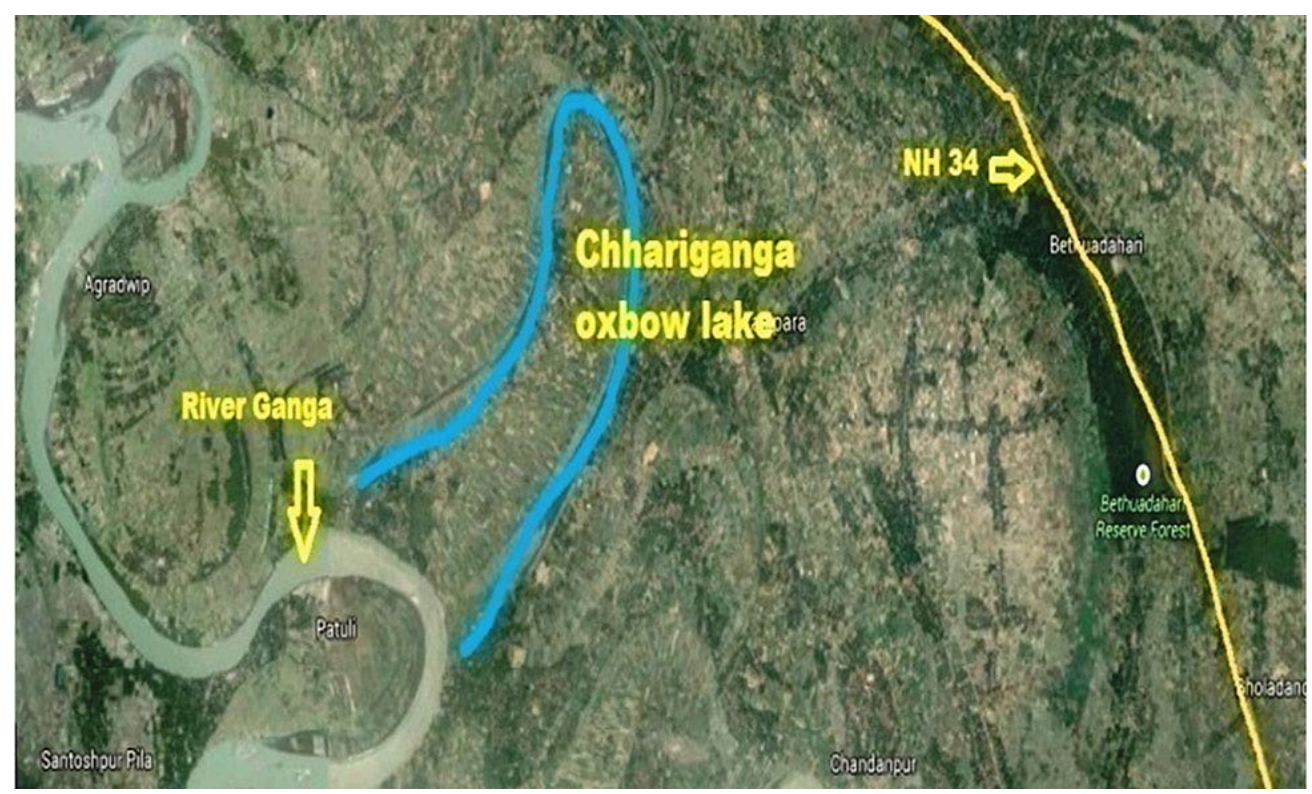

Figure 1. Map showing the study area, scale in $2 \mathrm{~km}$, triangles show sampling locations (downloaded and modified on 26.06.2016 from: Google maps.)

"Chhariganga Oxbow lake" in Santipur covering a total recorded area of 207.20 ha. This lake is important because it accounts for around $8.69 \%$ of the total oxbow lake Government area of water bodies and is probably the sole example of a semi-closed type oxbow lake in the district. This oxbow lake has an estimated average effective water spread area (EWSA) of 33.33 ha, that accounts for about $57 \%$ of a recorded water body area (RAW) of 58.28 ha, as registered by the land and land revenue department of West Bengal from April 2013 to March 2014. In this 12-month period, flood water entered the lake enhancing its EWSA and its annual average water depth of $2.55 \mathrm{~m}$. Thus, the volume of the EWSA (in millions of tons) was estimated to be $0.42,1.50,0.77$, 0.85 , and 0.90 for pre-monsoon, monsoon, post-monsoon, annual average, and annual total, respectively. The Chhariganga oxbow lake has on average 600 jute retting units of mean size $30 \mathrm{~m}^{2}$, with each unit covering about $3.6 \%$ of the EWSA (3.09\% of RAW) and consuming a water volume of more than $5 \%$ of the total EWSA annual average during monsoon (Table 1) Ultimately, the present study focused on $28.13 \%$ of the whole Chhariganga's recorded area $\left(2.44 \%\right.$ and $11^{\text {th }}$ largest of the total oxbow lakes as public water bodies in the district) which is in Nakashipara Block. 
Table 1. Mean and standard deviation of the water physicochemical variables measured in the Ojo de Agua Uriburu lake between December 2012 and July 2013.

\begin{tabular}{|c|c|c|c|c|c|}
\hline $\begin{array}{l}\text { OXBOW LAKE'S } \\
\text { ATTRIBUTES }\end{array}$ & PRM & MON & POM & $\begin{array}{c}\text { YR } \\
\text { AVERAGE }\end{array}$ & $\begin{array}{c}\text { YR } \\
\text { TOTAL }\end{array}$ \\
\hline RAW (ha) & 58.28 & 58.28 & 58.28 & 58.28 & 58.28 \\
\hline RAW (sqm) & 582800 & 582800 & 582800 & 582800 & 582800 \\
\hline Average Length (m) & 2500 & 2500 & 2500 & 2500 & 2500 \\
\hline Average Width (m) & 80 & 200 & 120 & 133 & 133 \\
\hline EWSA (sqm) & 200000 & 500000 & 300000 & 333333 & 333333 \\
\hline EWSA (ha) & 20 & 50 & 30 & 33.33 & 33.33 \\
\hline Average Depth (ft) & 7 & 10 & 8.5 & 8.50 & 8.50 \\
\hline Average Depth (m) & 2.1 & 3.0 & 2.55 & 2.55 & 2.55 \\
\hline Volume of EWSA (m3) & 420000 & 1500000 & 765000 & 850000 & 895000 \\
\hline Volume of RAW (m3) & 1223880 & 1748400 & 1486140 & 1486140 & 1486140 \\
\hline $\begin{array}{l}\text { Volume of EWSA (million } \\
\text { ton) }\end{array}$ & 0.42 & 1.50 & 0.77 & 0.85 & 0.90 \\
\hline Jute retting units & - & 600 & - & 600 & 600 \\
\hline $\begin{array}{l}\text { Jute retting area per unit } \\
\text { (sqm) }\end{array}$ & - & 30 & - & 30 & 30 \\
\hline Jute retting Total area (sqm) & - & 18000 & - & 18000 & 18000 \\
\hline Jute retting area (ha) & - & 1.80 & - & 1.80 & 1.80 \\
\hline Jute retting area $\%$ EWSA & - & 3.60 & - & 5.40 & 5.40 \\
\hline Jute retting area $\%$ RAW & - & 3.09 & - & 3.09 & 3.09 \\
\hline $\begin{array}{l}\text { volume of water for jute } \\
\text { retting }(\mathrm{m} 3)\end{array}$ & - & 54000 & - & 45900 & 45900 \\
\hline $\begin{array}{l}\text { Water required }(\%) \text { of } \\
\text { EWSA for jute retting }\end{array}$ & - & 3.60 & - & 5.40 & 5.13 \\
\hline $\begin{array}{l}\text { Water required }(\%) \text { of RAW } \\
\text { for jute retting }\end{array}$ & - & 3.09 & - & 3.09 & 3.09 \\
\hline
\end{tabular}


Physicochemical Analyses

\section{Collection of Water and Sediment Samples}

For well mixed waters (i.e. water free from any aquatic weed and not isolated by any fishing enclosure), a sample was taken within $1 \mathrm{~m}$ below the surface and away from the edge. To collect a sample of the surface layer, a $500 \mathrm{ml}$ polypropylene bottle was held horizontally and half submerged. All samples for chemical analysis were taken between 8 and 9 am of the sampling day. Sediment was collected from different locations and depths of the Chhariganga oxbow lake ecosystem and mixed thoroughly. All collected samples were pooled into one to make a composite sample for chemical analyses.

\section{Water physicochemical parameters}

Water physicochemical parameter analyses were carried out during the pre-monsoon, monsoon and post-monsoon seasons (from April 2013 to March 2014). Analyzed parameters for all water samples included: (i) temperature, recorded on the spot with a WTW Multi-parameter portable meter MultiLine ${ }^{\circledR}$ (F/SET-3, Weilheim, Germany); (ii) transparency, assessed with a metallic Secchi disc of $20 \mathrm{~cm}$ in diameter with four quadrants of alternate black and white colors on the upper surface. The disc was ballasted on the lower surface and suspended with a graduated cord at its center. (iii) Water $\mathrm{pH}$, measured using a WTW Multi-parameter portable meter MultiLine ${ }^{\circledR}$ (F/SET-3, Weilheim, Germany). For $\mathrm{pH}$, the averaging across samples procedure described by Boyd (1992) was used, $\mathrm{pH}$ readings were converted to hydrogen ion concentrations and these were then averaged. (iv) Dissolved oxygen in the lake water was measured with a specific probe of a WTW Multi-parameter portable meter MultiLine ${ }^{\circledR}$ (F/SET-3, Weilheim, Germany). (v) Biochemical oxygen demand (BOD) was obtained following Selvaraj (2005) and Ghosh \& Biswas (2015c). This is an in situ method that consisted of filling an $250 \mathrm{ml}$, airtight bottle and incubating it at in situ temperature for 1 day. Dissolved oxygen (DO) was measured, by the Winkler method, before and after incubation, and the BOD was computed from the difference between initial and final DO. (vi) Chemical oxygen demand (COD) was determined using a digestion mixture of $0.25 \mathrm{~N}$ potassium dichromate and concentrated $\mathrm{H}_{2} \mathrm{SO}_{4}$ (5:1) with $1 \mathrm{~g}$ of $\mathrm{AgSO}_{4}$ and titrating against ferrous ammonium sulphate taking phenanthroline as indicator (Golterman \& Ohnstad, 1978).

(vii) Ammonium nitrogen $\left(\mathrm{NH}_{4}-\mathrm{N}\right)$ was measured at $654 \mathrm{~nm}$, following the modified phenate method (Wetzel \& Likens, 1991) with a Shimadzu UV-visible spectrophotometer Model UV-1601 (Kyoto, Japan). 
(viii) The concentration of nitrite nitrogen $\left(\mathrm{NO}_{2}-\mathrm{N}\right)$ was measured at 543 $\mathrm{nm}$ in a spectrophotometer (Shimadzu, Model UV-1601, Kyoto, Japan) using $\alpha$-naphthylamine and sulphanilic acid (Wetzel \& Likens, 1991). (ix) The concentration of nitrate nitrogen $\left(\mathrm{NO}_{3}-\mathrm{N}\right)$ was determined by UV-spectrophotometric method (APHA, 1998) using aluminum hydroxide suspension and $1 \mathrm{~N} \mathrm{HCL}$ at $220 \mathrm{~nm}$ and $275 \mathrm{~nm}$ in a spectrophotometer (Shimadzu, Model UV-1601, Kyoto, Japan). The measurement of the ultraviolet absorption at $220 \mathrm{~nm}$ enabled rapid determination of nitrate nitrogen, and because dissolved organic matter may also absorb at $220 \mathrm{~nm}$, a second measurement was made at $275 \mathrm{~nm}$ to correct the nitrate nitrogen value. (x) Orthophosphate (OP) content of the lake water was determined colorimetrically at $690 \mathrm{~nm}$ in a spectrophotometer (Shimadzu, Model UV-1601, Kyoto, Japan) following the stannous chloride method (APHA, 1998). (xi) Total alkalinity was determined by titration of a lake water sample with sulphuric acid $(0.02 \mathrm{~N})$. Alkalinity due to hydroxide and carbonate was determined to the first end point $(\mathrm{pH}$ 8.3) using phenolphthalein as indicator, and bicarbonate alkalinity was determined to the second end point $(\mathrm{pH} 4.5)$ using methyl orange (APHA, 1998). Finally, (xii) water total hardness was determined in alkaline medium with 2-3 drops of eriochrome black-T indicator, by titration against standard $0.01 \mathrm{M}$ ethylene diamine tetra acetic acid (EDTA) until the red wine color of the solution turns pale blue at the end point (APHA, 1998).

\section{Sediment physicochemical parameters}

Sediment $\mathrm{pH}$ of the Chhariganga oxbow lake was measured with a potentiometer upon direct reading using a glass electrode with a saturated $\mathrm{KCl}$-calomel reference electrode (Water resources department, 2009). For estimation of sediment organic carbon, a 500-mg, dried, and powdered sediment sample was taken and digested with $20 \mathrm{ml}(1 \mathrm{~N}) \mathrm{K}_{2} \mathrm{Cr}_{2} \mathrm{O}_{7}$ and $20 \mathrm{ml} \mathrm{H}_{2} \mathrm{SO}_{4}$ (concentrated) then kept for 30 minutes in a dark place. The sample was then diluted with $150 \mathrm{ml}$ distilled water and $10 \mathrm{ml}$ phosphoric acid, and $1 \mathrm{ml}$ diphenylamine indicator were added to it. The sample was then titrated against $0.5 \mathrm{~N}$ ferrous ammonium sulphate (Mohr's salt) until a brilliant green color appeared.

\section{Macroinvertebrate Collection, Preservation and Identification}

Macroinvertebrates were collected in each season (pre-monsoon, monsoon, and post-monsoon) in ten different locations in the lake, from April 2013 to March 2014 (Fig. 1). At each sampling location, collections were done using a D-frame net of $0.5 \mathrm{~mm}$ mesh size, and consisted of 100 samples in 
an area of $1 \mathrm{~m}^{2}$. Pupae and other macroinvertebrates attached to the bushes were washed into a hand net made of mesh bolting silk of $100 \mu \mathrm{m}$. Water was added and stirred vigorously on floating fauna while sieving to handpick the non-floating fauna through a $250 \mu \mathrm{m}$ mesh sized net. As the depth of the oxbow lake ranges from 0.6 to $3.0 \mathrm{~m}$ (Table 1), a dip net was used in shallow water, and an Ekman's grab in deeper water was used to retrieve sediments from the bottom.

One sediment sample was collected from the bottom in a plastic container of $15 \mathrm{~L}$ at each sampling location in the lake in every season (Ghosh \& Biswas, 2015b; Obolewski, 2016). All samples collected from the ten different locations were combined into a single composite sample for a particular sample day. Pooled samples were fixed in formaldehyde (4\%) in the field and transferred to $70 \%$ ethyl alcohol for preservation after sorting in the laboratory. Macroinvertebrates were sorted and identified to the family level with the help of identification keys and available literature (Pennak, 1989; Edmondson, 1993; Merrit \& Cummins, 1994; Jessup et al. 2003; Subramanian \& Shivaramakrishnan, 2005; 2007; Stroud Water Research Centre, 2015) as identification at the family level awards more precision to the taxonomists and requires less expertise and time to complete (Barbour et al. 1999). Considering this, and counted under a stereomicroscope in the laboratory, relative abundance of macroinvertebrates was calculated as percentage composition (\%) and their total occurrences in numbers divided by total sampled water volume at each sampling site was referred to as mean macroinvertebrate density $\left(\mathrm{n} / \mathrm{m}^{3}\right)$ for the oxbow lake. The annual mean macroinvertebrate density was obtained as the average macroinvertebrate density of the three sampling seasons.

\section{Pollution Tolerance Index determination}

Seasonal Pollution Tolerance Index (PTI) for the Chhariganga oxbow lake was obtained following the methodology established by Olomukoro \& Dirisu (2014). Briefly, sampled macroinvertebrate families were assigned to three groups, namely pollution intolerant, moderately tolerant, and tolerant. Each category was then scored with a sensitivity factor; a factor of 3 was given to the pollution sensitive (intolerant) group, a factor of 2 to the facultative or moderately tolerant group, and a factor of 1 to the pollution tolerant group. Sensitivity factors of macroinvertebrate families, as defined by Olomukoro \& Dirisu (2014), are shown in (Table 2). The products of the number of occurrence of each family by its respective sensitivity factor were summed to obtain the PTI for each sampling point within each sampling season. 
Table 2. Pollution sensitivity scores of macroinvertebrate families according to Olomukoro \& Dirisu (2014).

\begin{tabular}{|c|c|c|}
\hline SL NO & FAMILY & SENSITIVITY SCORE \\
\hline 1 & Elmidae & 3 \\
\hline 2 & Hydrachnidae & 3 \\
\hline 3 & Unionidae & 3 \\
\hline 4 & Viviparidae & 3 \\
\hline 5 & Macromiidae & 2 \\
\hline 6 & Chironomidae & 2 \\
\hline 7 & Ceratopogonidae & 2 \\
\hline 8 & Platycnemididae & 2 \\
\hline 9 & Palaemonidae & 2 \\
\hline 10 & Potamidae & 2 \\
\hline 11 & Corixidae & 1 \\
\hline 12 & Nepidae & 1 \\
\hline 13 & Hydrometridae & 1 \\
\hline 14 & Gerridae & 1 \\
\hline 15 & Hydrophilidae & 1 \\
\hline 16 & Culicidae & 1 \\
\hline 17 & Physidae & 1 \\
\hline 18 & Hirudinidae & 1 \\
\hline 19 & Lumbricidae & 1 \\
\hline
\end{tabular}

Thereafter, obtained PTIs were compared with reference PTIs as shown in (Table 3) (i.e. unpolluted water values between 23 and above, excellent; 17-22 good, 11-16 fair; and below 10 poor).

\section{Data Analyses}

Mean, standard deviation and the degree of relationships among different physicochemical factors of water and sediment were determined using linear regression with the help of MS-Excel. The level of statistical significance was accepted at $\mathrm{P}<0.05$. 
Table 3. Water quality rating according to Pollution Tolerance Index values.

\begin{tabular}{cc}
\hline PTI VALUES & WATER QUALITY RATING \\
\hline$\geq 23$ & Excellent (Unpolluted water) \\
$17-22$ & Good (Unpolluted water) \\
$11-16$ & Fair (polluted water) \\
$\leq 10$ & Poor (polluted water) \\
\hline
\end{tabular}

\section{Result and discussions}

\section{Water and sediment physicochemical variables}

In the Chhariganga oxbow lake, according to physicochemical water parameter analyses, except for water transparency, $\mathrm{BOD}_{1}, \mathrm{NO}_{2}-\mathrm{N}$, and water OP content almost all assessed parameters did not show significant changes throughout the year. Mean annual values for the 12 measured physicochemical variables of the lake, are shown in Table 4 and (Fig. 2a and $\mathbf{2 b})$; sediment $\mathrm{pH}(6.8-7.9,7.53 \pm 0.34)$ and percent of sediment organic carbon $(1.87-2.89,2.17 \pm 0.28)$ in Fig. 3. The highest mean values for $\mathrm{BOD}_{1}$ COD, OP were $4.59 \mathrm{ppm}, 86.67 \mathrm{ppm}, 0.50 \mathrm{ppm}$, respectively and were observed during monsoon. Whereas in the same season, when jute retting process gets intensified in the lake, the lowest values of water's transparency $(27.00 \mathrm{~cm}), \mathrm{pH}(7.84), \mathrm{DO}(3.63 \mathrm{ppm})$ and $\mathrm{NO}_{2}-\mathrm{N}$ content $(0.01 \mathrm{ppm})$ were recorded (Fig. 2a, 2b, and 3). Compared to their values in pre-monsoon, monsoon mean values of the following water quality parameters showed an increase in the following proportions: $\mathrm{BOD}_{1}(182.57 \%)$, COD $(18.18 \%)$, $\mathrm{NH}_{4}-\mathrm{N}(7.87 \%), \mathrm{NO}_{3}-\mathrm{N}(17.73 \%)$, OP content (167.64\%), sediment organic carbon content $(10.11 \%)$, and $\mathrm{pH}$ values $(7.36 \%)$. Whereas reductions were observed for the following parameters: water transparency $(62.54 \%), \mathrm{pH}$ $(5.74 \%), \mathrm{DO}(22.16 \%), \mathrm{NO}_{2}-\mathrm{N}(65.68 \%)$, total hardness $(21.63 \%)$ and total alkalinity $(24.27 \%)$.

During pre-monsoon the Chhariganga oxbow lake experienced the highest mean water transparency $(72.07 \mathrm{~cm}$, representing a $78.87 \%$ rise over post-monsoonal mean), water temperature $\left(31.5^{\circ} \mathrm{C}\right)$, total hardness (123.86 ppm, representing a $45.29 \%$ increase over post-monsoonal mean) and total alkalinity (147.64 ppm, $49.64 \%$ hike over post-monsoonal mean). 


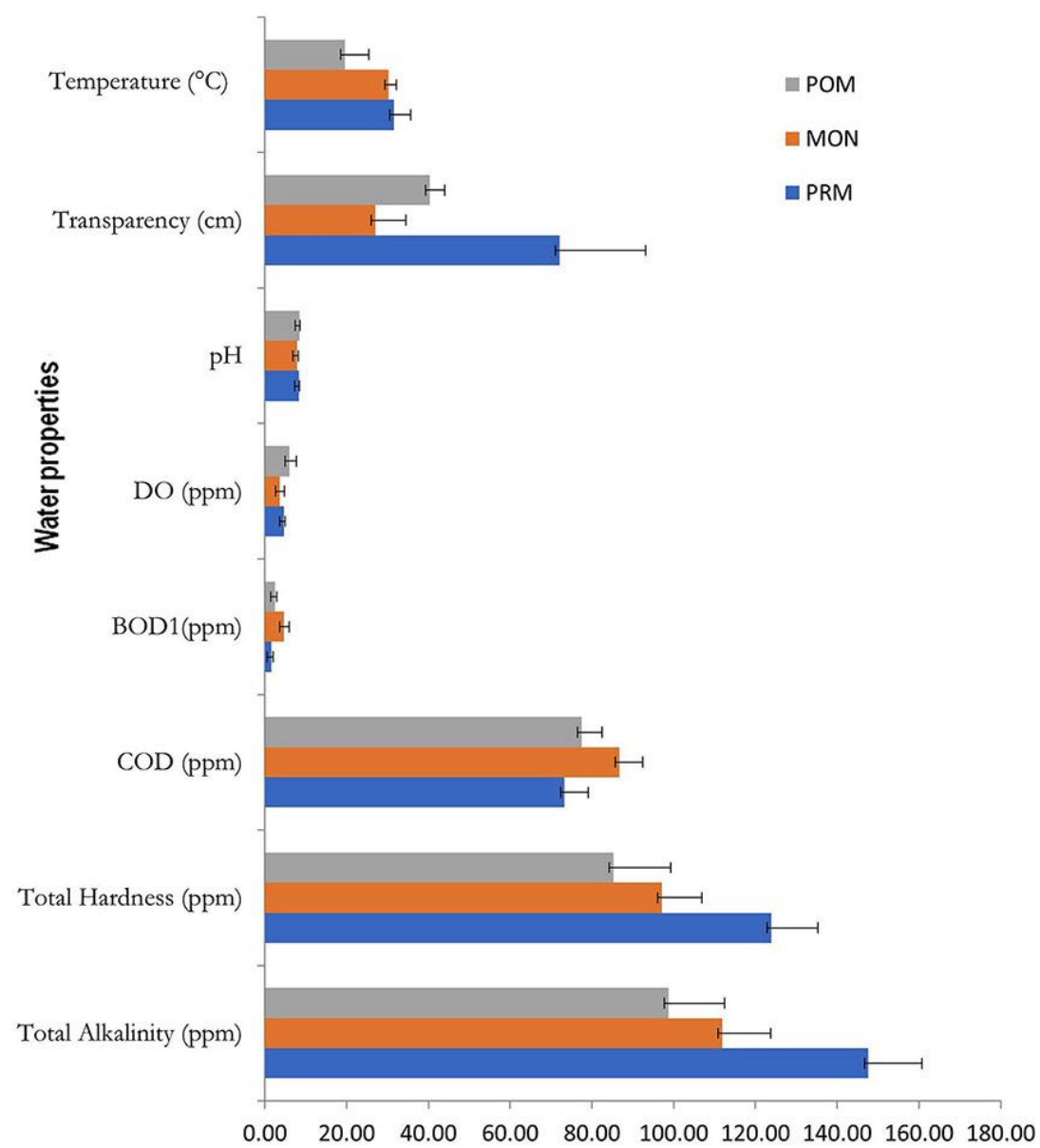

(a)

Values

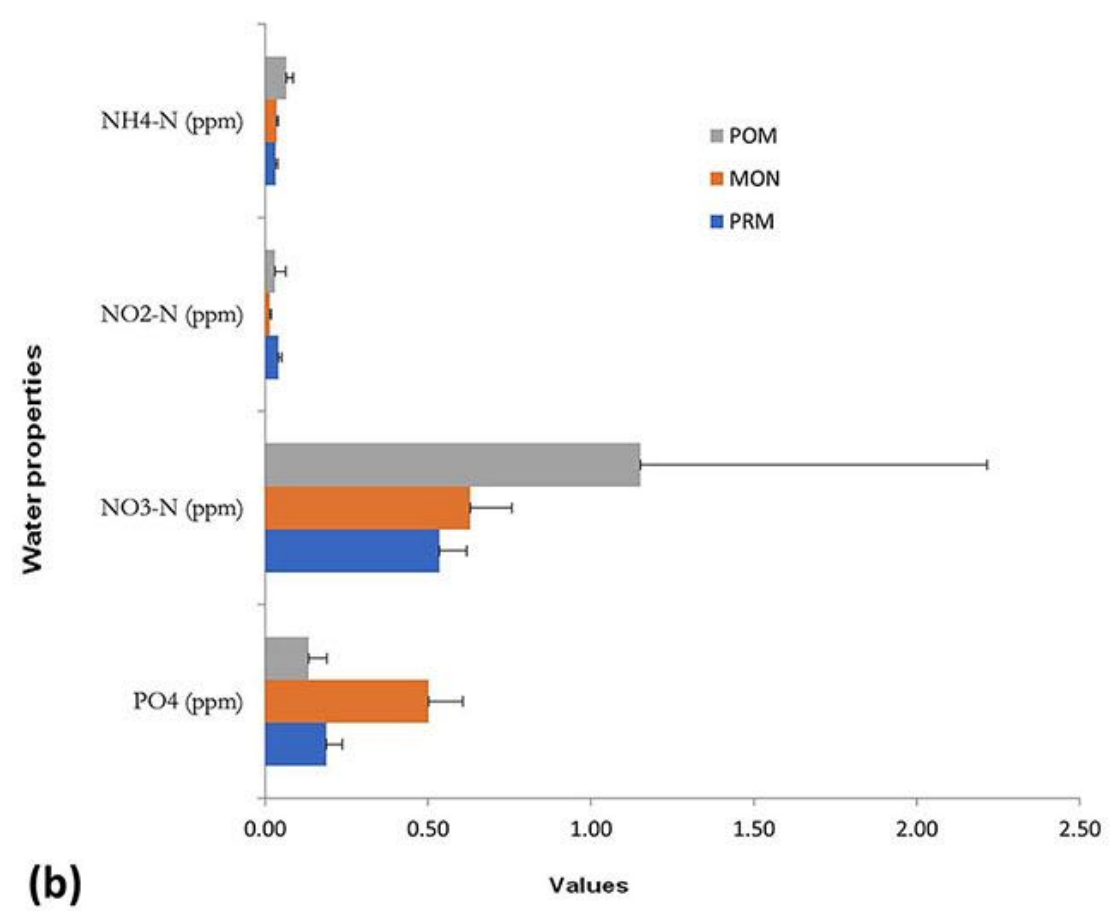

Figure $2 \mathrm{a}$ and $2 \mathrm{~b}$. Variation in water parameters. 
Table 4. Physicochemical variables of the lake's water.

\begin{tabular}{|c|c|c|}
\hline Parameter & Range & $\begin{array}{c}\text { Annual } \\
\text { mean } \pm \text { standard } \\
\text { deviation }\end{array}$ \\
\hline Surface water temperature in ${ }^{\circ} \mathrm{C}$ & $11-37$ & $27.64 \pm 6.56$ \\
\hline Water transparency in $\mathrm{cm}$ & $16-106$ & $45.82 \pm 23.39$ \\
\hline Water $\mathrm{pH}$ & $7.4-8.8$ & $8.17 \pm 0.34$ \\
\hline Dissolved oxygen content (DO) in ppm & $2.60-7.85$ & $4.65 \pm 1.52$ \\
\hline Biochemical oxygen demand $\left(\mathrm{BOD}_{1}\right)$ in ppm & $1.10-6.40$ & $2.98 \pm 1.59$ \\
\hline Chemical oxygen demand (COD) in ppm & $70-90$ & $79 \pm 7.38$ \\
\hline Ammonium nitrogen content $\left(\mathrm{NH}_{4}-\mathrm{N}\right)$ in $\mathrm{ppm}$ & $\begin{array}{c}0.026- \\
0.093\end{array}$ & $0.05 \pm 0.02$ \\
\hline Nitrite nitrogen content $\left(\mathrm{NO}_{2}-\mathrm{N}\right)$ in $\mathrm{ppm}$ & $0.008-0.08$ & $0.03 \pm 0.02$ \\
\hline Nitrate nitrogen concentration $\left(\mathrm{NO}_{3}-\mathrm{N}\right)$ in ppm & $0 \quad 2.459$ & $0.81 \pm 0.69$ \\
\hline Orthophosphate concentration (OP) in ppm & $0.067-0.62$ & $0.26 \pm 0.18$ \\
\hline Total alkalinity in ppm & $82-165$ & $120 \pm 24.03$ \\
\hline Total hardness in ppm & $70-138$ & $102.62 \pm 19.60$ \\
\hline
\end{tabular}

In addition, the oxbow lake's lowest values were also observed during pre-monsoon in $\mathrm{BOD}_{1}(1.63 \mathrm{ppm}, 32.33 \%$ fall in post-monsoonal mean), COD (73.33 ppm, $5.38 \%$ decrease of post-monsoonal mean), $\mathrm{NO}_{3}-\mathrm{N}(0.53$ ppm, $53.62 \%$ decrease $)$ of post-monsoonal mean, sediment $\mathrm{pH}$ (7.14) and sediment organic carbon (2.08\%). Compared to post-monsoon, during pre-monsoon changes in other parameters were observed: $\mathrm{DO}(21.91 \%$ decrease), $\mathrm{NH}_{4}-\mathrm{N}$ ( $50.75 \%$ decrease) and $\mathrm{NO}_{2}-\mathrm{N}$ (35.31\% increase), OP ( $41.17 \%$ increase).

In this lake, during the post-monsoon season the highest recorded parameter mean values were the following: water $\mathrm{pH}(8.42)$; $\mathrm{DO}$ (5.96 ppm, representing a $64.52 \%$ rise over the monsoonal mean); $\mathrm{NH}_{4}-\mathrm{N}(0.07 \mathrm{ppm}$, that accounts for an $88.21 \%$ hike on the corresponding monsoonal mean); $\mathrm{NO}_{3}-\mathrm{N}(1.15 \mathrm{ppm})$; and sediment $\mathrm{pH}$ (7.80). Furthermore, also during post-monsoon, the lowest 
mean parameter values were observed for water temperature $\left(19.56{ }^{\circ} \mathrm{C}\right)$, OP ( $0.13 \mathrm{ppm}, 73.53 \%$ dip), total hardness ( $85.25 \mathrm{ppm}$ ) and total alkalinity (98.67 ppm). Additionally during post-monsoon, changes respect to monsoon values were observed for $\mathrm{NO}_{2}-\mathrm{N}$ content (115.34\% increase), COD (10.58\% decrease), $\mathrm{BOD}_{1}$ (47.70\% decrease), transparency (increased by $49.23 \%$ ) and sediment's organic carbon content (5.54\% decrease).

The highest concentrations of $\mathrm{NH}_{4}-\mathrm{N}$ and $\mathrm{NO}_{3}-\mathrm{N}$ were observed during post-monsoon and the highest $\mathrm{OP}$ values during monsoon. Water transparency mean values showed a sharp decrease as monsoon followed pre-monsoon. During monsoon, the elevated levels of orthophosphate, COD, and $\mathrm{BOD}_{1}$ as well as the reduced levels of $\mathrm{DO}$, water $\mathrm{pH}$, and transparency (Fig. 2a and 2b) were also attributed to the jute retting and influx of turbid water into the oxbow lake ecosystem. A higher variations in sediment organic carbon content (Fig. 3). were noticed during the monsoon due to obvious reason of jute retting.

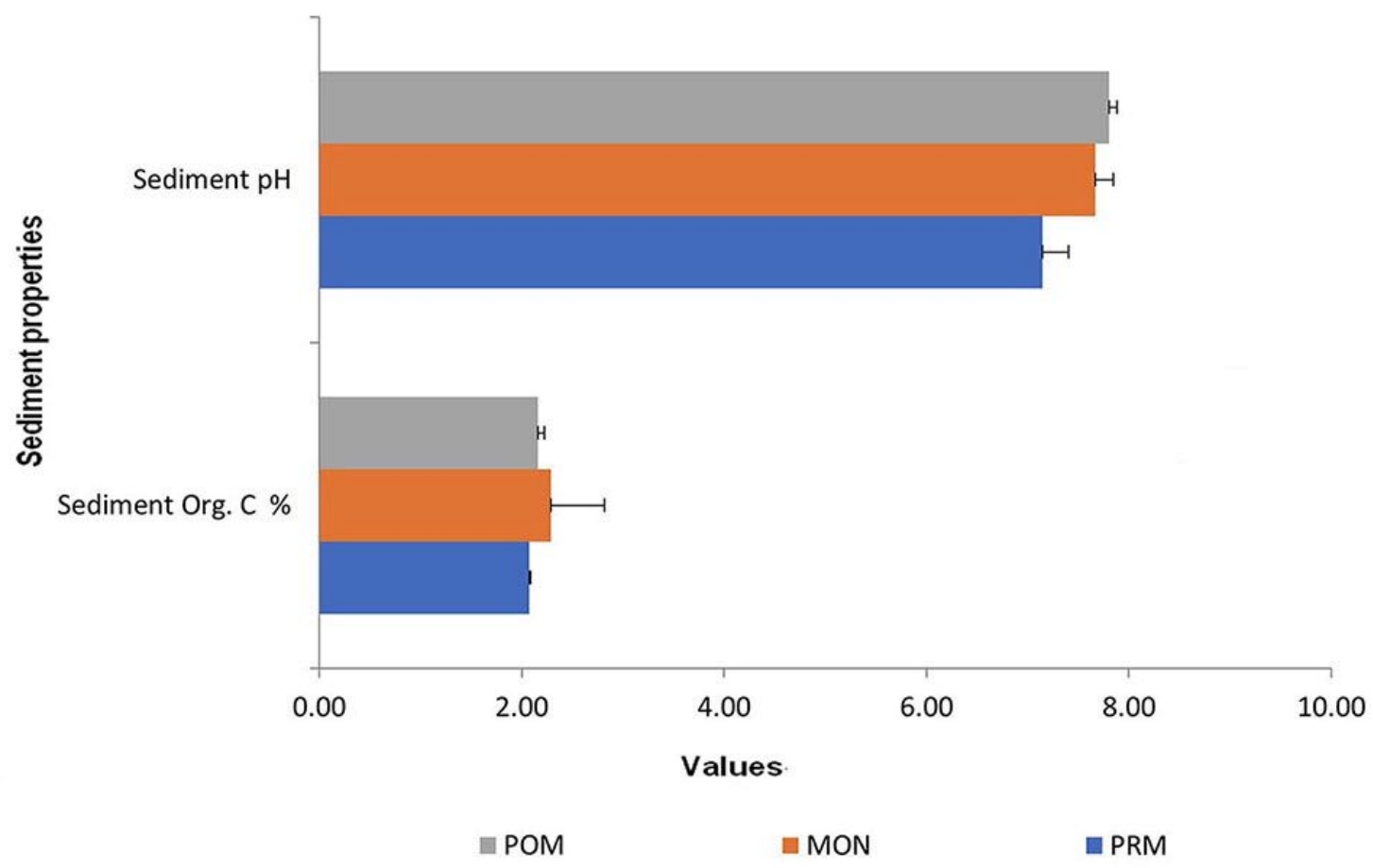

Figure 3. Variation in sediment properties. 
Water and sediment health condition as revealed by physicochemical analyses

Values of the assessed physicochemical parameters for the Chhariganga oxbow lake during monsoon were elevated, compared to their values in pre-monsoon, and the same trend was observed with lake sediment analyses results. Such a general parameter value increase may be due to jute retting and to a high inflow of organic matter. The highest concentrations of $\mathrm{NH}_{4}-\mathrm{N}$ and $\mathrm{NO}_{3}-\mathrm{N}$, observed during post-monsoon, and of OP, recorded during monsoon, may also be due to the allochthonous organic input and decomposition of aquatic macrophytes, as well as to jute retting. The sharp decrease in mean values for water transparency during monsoon compared to pre-monsoon indicate a high level of total dissolved solids due to a heavy load of light penetration restricting organic matter in this lake. Consequently, the concentration of dissolved oxygen decreased due to a reduced photosynthetic rate. The statistically significant changes in water transparency, $\mathrm{BOD}_{1}$, and $\mathrm{OP}$ content in the present study can be attributed to an overall organic pollution in the lake throughout the year, and especially during monsoon. This physicochemical parameter study reveals that the high values of parameters like $\mathrm{pH}$, total hardness, total alkalinity, orthophosphate, and the low values of water transparency, DO, BOD, and COD reflect a poor to moderate water quality with a moderate to high organic pollution in the system.

\section{PTI of macroinvertebrates}

The present study reported macroinvertebrates of 19 families in 3 phyla. Marcorinvertebrate seasonal occurrence, relative abundance, and pollution tolerance levels are given in Suppl.1 Relative abundance as percentage composition and seasonal occurrence of individuals classified under different pollution groups (pollution sensitive or intolerant, moderately tolerant, and tolerant) are given in Suppl. 2 and (Fig. 4). Macroinvertebrates of the pollution tolerant group dominated during all three seasons with frequencies of $55.81 \%, 90.25 \%$, and $79.06 \%$, for pre-monsoon, monsoon and post-monsoon, respectively. While families of the pollution-sensitive or intolerant group were the least frequent during pre-monsoon and post-monsoon, and were absent during monsoon. Macroinvertebrates of moderately pollution tolerant families had their maximum occurrence in the lake during post-monsoon and their minimum occurrence during pre-monsoon. In the Chhariganga oxbow lake, total mean macroinvertebrate density increased during the monsoon season compared to the other two seasons. Pollution tolerant and moderately tolerant macroinvertebrate groups 


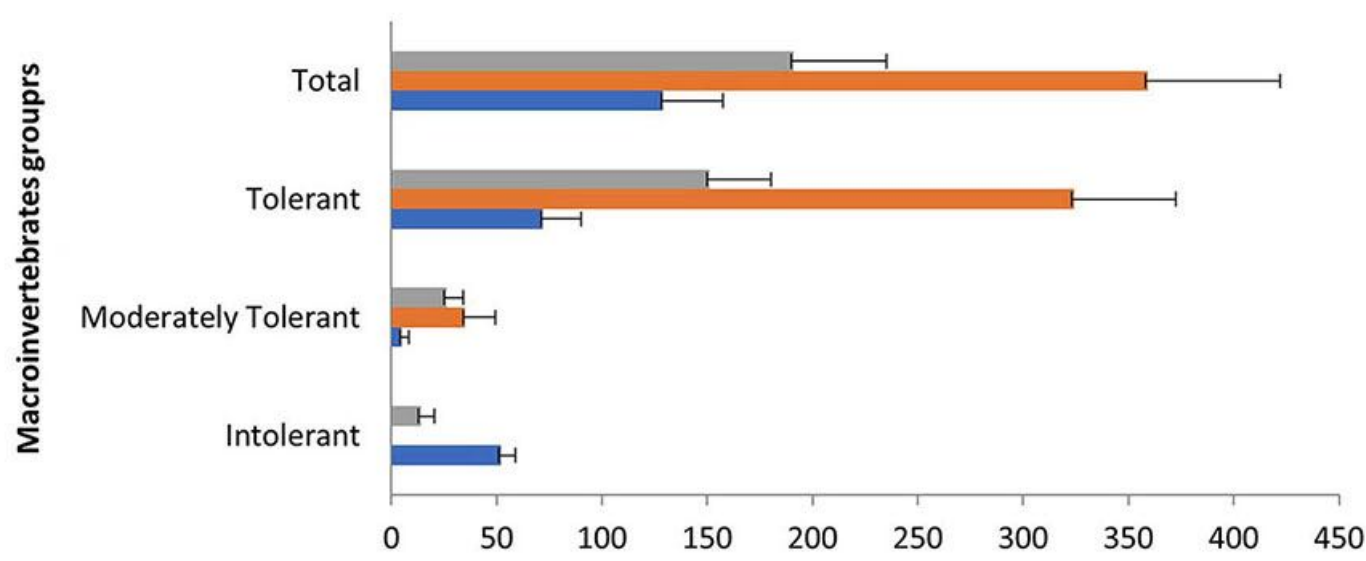

Mean density (No/m3)

- POM

$\square \mathrm{MON}$

a PRM

Figure 4. Seasonal abundance of pollution tolerance groups.

largely contributed to total mean density throughout the study, and intolerant groups were substantially reduced or absent during monsoon. This was due to an elevated organic pollution resulting from the jute retting process and a monsoonal influx of turbid water from the river Ganga (Fig. 4). and (Suppl. 2).

Detailed relative abundance as percentage composition, seasonal occurrence of family (richness), and pollution tolerance indexes of macroinvertebrates are given in Suppl. 3 and (Fig. 5). The richness of intolerant group was zero during monsoon (Fig. 5 and Suppl. 3). Leeches, as a pollution tolerant group, were only encountered in the post-monsoon sampling. They may not have been seen during rest of the year due to the profundity of the lake, high water turbidity (from the River Ganga during monsoon), and to the better pre-monsoonal environmental condition. Additionally, a limited sample size may be an additional reason why in the present study leaches were only found during post-monsoon. (Fig. 6) demonstrates the macroinvertebrate taxa frequency distributions in the lake ecosystem. The phylum Arthropoda class Insecta had the biggest share among all observed phyla (Fig. 6).

In the light of another study conducted in parallel for the same water system (Ghosh \& Biswas, 2015 b), macroinvertebrate density and standing biomass in 
the Chhariganga oxbow lake were observed to be strongly and positively correlated with the lake's BOD, orthophosphate content, and sediment organic content. Macroinvertebrate richness was positively correlated with water $\mathrm{NO}_{3}-\mathrm{N}$ content, and macroinvertebrate Shannon Weiner Diversity Index (SWI) values with water $\mathrm{pH}$. Inverse correlations were found between macroinvertebrate density and both water transparency and $\mathrm{pH}$ level; and between water orthophosphate content and macroinvertebrate SWI values.

\section{Aquatic health assessment based on PTI}

PTIs obtained in the present study differ considerably from those obtained from the assessment of the health status of the wetlands in Southern Nigeria (Olomukoro \& Dirisu, 2014). The obtained high PTIs (Suppl 2) suggest that during pre-monsoon and post-monsoon, water in the lake was in an excellent and unpolluted condition; whereas the slightly lower PTI values obtained during the monsoon, and throughout the year, are indicative of a good and unpolluted water with low or no anthropogenic activity.

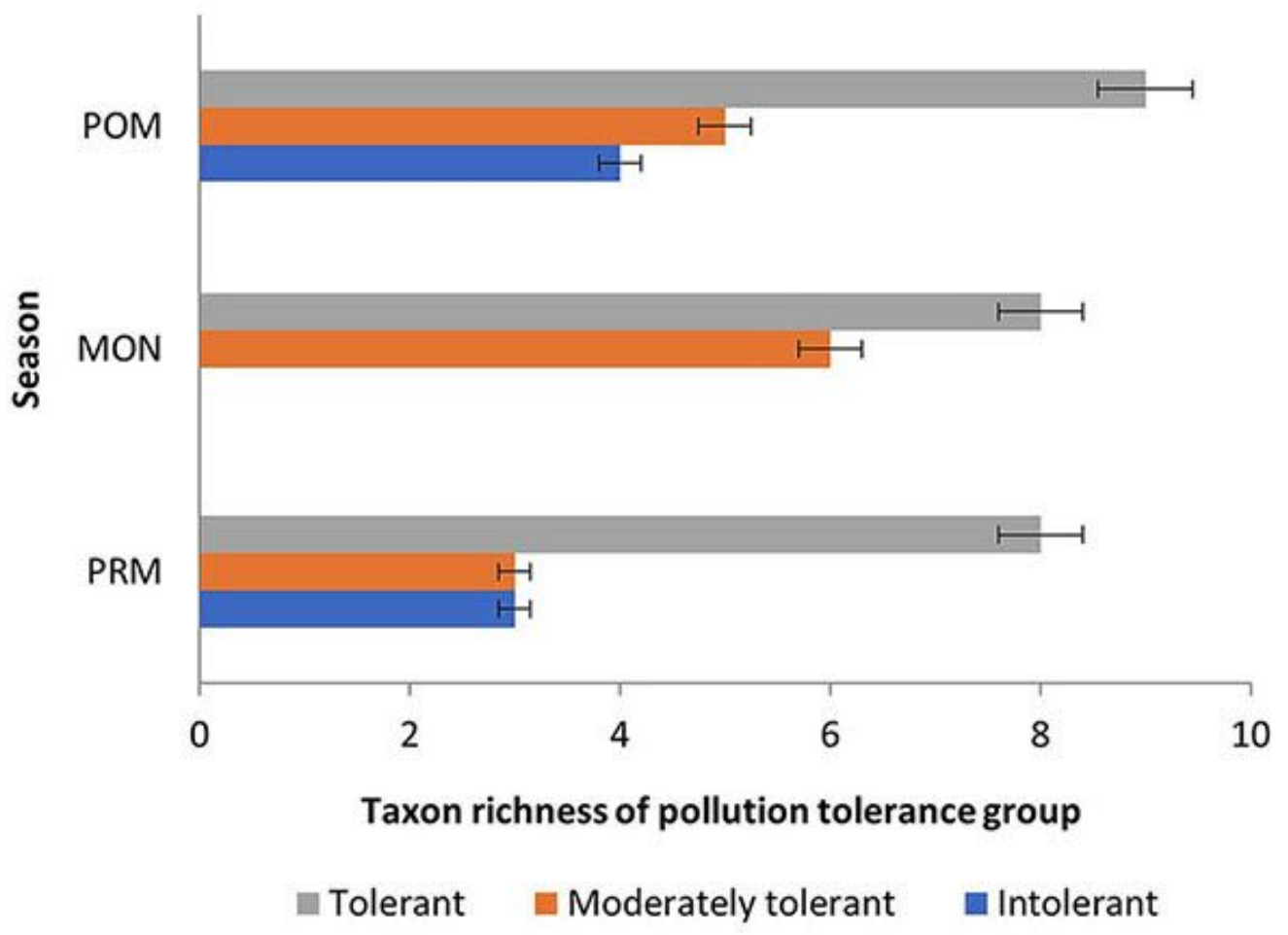

Figure 5. Taxon richness distribution per pollution tolerance group. 


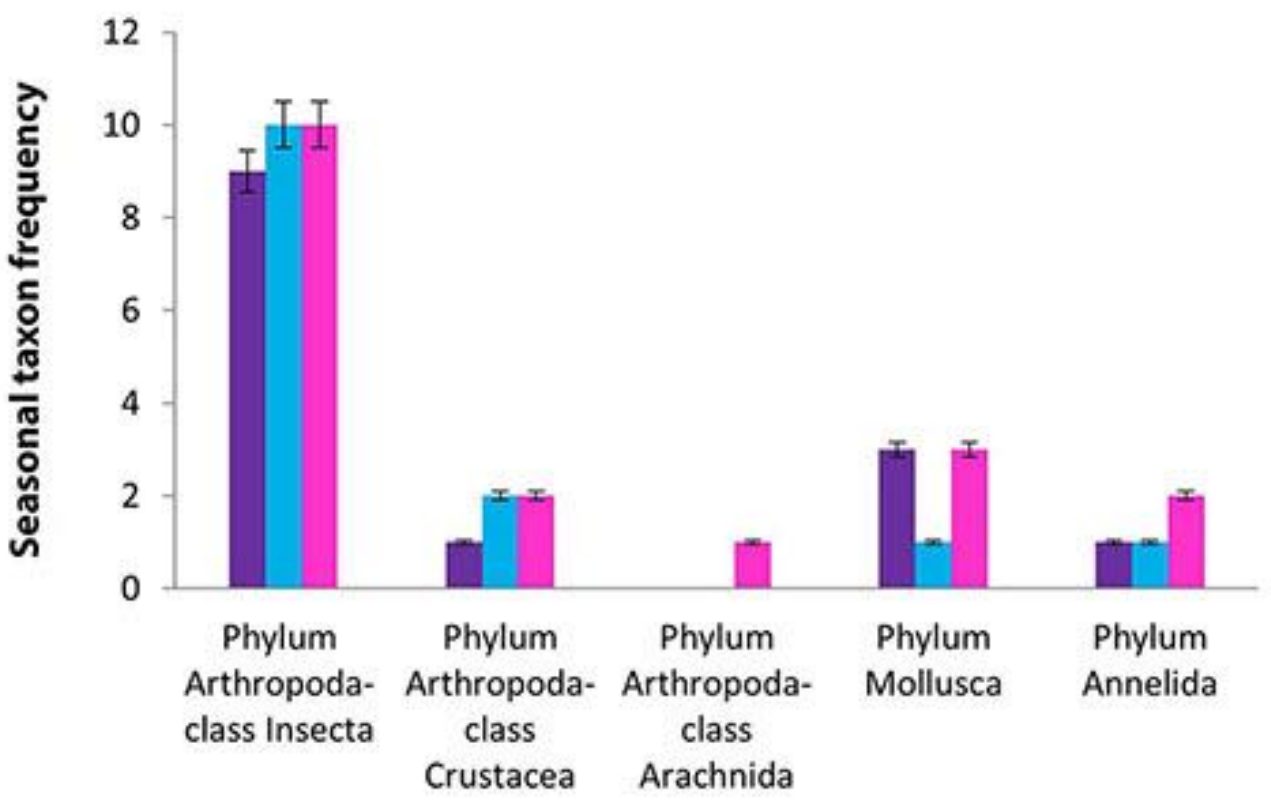

Macroinvertebrate phyla

a PRM

$=\mathrm{MON}$

POM

Figure 6. Macroinvertebrate taxa frequency distributions.

Water health condition as revealed by biodiversity indices

Obtained PTI values in this study do not concur with the poor health status of the lake as revealed by the low values of the SWI and Simpson diversity index (ranging from 0.29 to 2.12) for macroinvertebrates (Suppl.4). These two indexes were calculated with the same data of the present study but were published elsewhere (Ghosh \& Biswas, 2015 b). Their low values reflect an overall bad-to-poor state of the lake's health, a poor water quality, especially during monsoon, and can be attributed to high intensity jute retting activity. The conclusion of a poor health status, drawn from these macroinvertebrate diversity indexes, is also supported by the findings of previous studies, on the same lake, in which low diversity index values were obtained for rotifers (Ghosh \& Biswas, 2014), zooplankton (Ghosh \& Biswas, 2015 a), macrophyte (Ghosh \& Biswas, 2015 d), phytoplankton (Ghosh \& Biswas, 2015 e), fish (Ghosh \& Biswas, 2017 a; 2017 c), and fish productivity (Ghosh \& Biswas, $2017 \mathrm{~b}$ ). Because of their tolerance to pollution, Oligochaetes are important bioindicators and provide a criterion for an ecological lake classification (Rashid \& Pandit, 2014). As deposit feeders, their presence in the Chhariganga 
oxbow lake is an indication of organic matter richness, and their tolerance to silting and decomposition confirms the degree of organic pollution in the system caused by jute retting.

\section{Conclusions}

The pollution status of lake Chhariganga, as revealed by the obtained PTIs, is not corroborated by the macroinvertebrate diversity assessment derived from the same data, nor is it further supported by the results of rotifer, zooplankton, macrophyte, and phytoplankton studies, conducted by Ghosh \& Biswas (2015 b) in parallel with the present study. Physicochemical analyses too confirmed the precarious to poor state of the lake's health. The presence of earth worms throughout the year also confirmed the lake's organic pollution. Therefore, we conclude that macroinvertebrate PTI values alone are not reliable aquatic health diagnostic tools unless they are complemented or contrasted to diversity indexes (e.g. SWI). However, ecological studies of macroinvertebrates are still necessary to understand lake ecosystems and their health. There remains a need to prevent, or regulate the intensity of, jute retting activity in the lake during monsoon in order to ensure a sustainable management and conservation of this aquatic environment and to enhance its biodiversity. The present study provides pivotal baseline data to various organizations, government, non-government agencies, as well as academic institutions to take actions that improve and lead to a more efficient and sustainable management of oxbow lakes.

\section{Conflict of interest}

The authors declare having no conflict of interest on any aspect of the research and results of the present work. The authors hereby pronounce no competing interests.

\section{Acknowledgments}

The authors acknowledge the support provided by the Department of Ecological Studies at the University of Kalyani; Department of Fisheries of the West Bengal Government, and the Kutirpara Fishermen Co-operative Society Ltd. of the Nakashipara Development Block, Nadia, West Bengal, India.

\section{References}

Alakananda B, Mahesh MK, Supriya G, Boominathan M, Balachandran C, Ramachandra TV. Monitoring Tropical Urban Wetlands through Biotic Indices, Journal of Biodiversity, 2(2): 91-106, 2011. 
American Public Health Association (APHA). Standard methods for the examination of water and wastewater, 20th ed. Clesceri LS, Greenberg AE, \& Eaton, AD, (Eds.); American Public Health Association: Washington, DC,1998.

Balachandran C, Dinakaran S, Alakananda B, Boominathan M, Ramachandra TV. Monitoring aquatic macroinvertebrates as indicators for assessing the health of lakes in Bangalore, Karnataka, International Journal of Advanced Life Sciences (IJALS), 5(1):19-33, 2012.

Balachandran C, Ramachandra TV. Aquatic Macroinvertebrate Diversity and Water quality of Bangalore Lakes, Lakes 2010: Wetlands, Biodiversity and Climate Change, 1:1-18, 2010.

Barbour MT, Gerritsen J, Snyder BD, Stribling JB. Rapid Bioassessment protocols for Use in Streams and wadeable Rivers: Periphyton, Benthic Macroinvertebrates, and Fish. Second Edition. EPA8419 B9999002. U.S. Environmental Protection Agency; Office of Water; Washington, D.C, 1999.

Birk S, Bonne W, Borja A, Brucet S, Courrat A, Poikane S, Solimini A, Bund WBD, Zampoukas N, Hering D. Three hundred ways to assess Europe's surface waters: an almost complete overview of biological methods to implement the Water Framework Directive, Ecological Indicators, 18: 31-41, 2012.

doi: 10.1016/j.ecolind.2011.10.009

Bonada N, Prat N, Resh VH, Statzner B. Developments in aquatic insect biomonitoring: a comparative analysis of recent approaches, Annual Review of Entomology, 51, 495-523, 2006

doi: 10.1146/annurev.ento.51.110104.151124

Boyd C, E. Water quality management for pond fish culture. Elsevier Scientific Publishing Company, Oxford. 1992

Chakrabarty D, Das SK. Alteration of macroinvertebrate community in tropical aquatic systems in relation to sediment redox potential and overlaying water quality, International Journal of Environmental Science and Technology, 2(4): 327-334, 2006.

doi: $10.1007 / \mathrm{BF} 03325893$

Clarke RT, John FW, Mike TF. RIVPACS models for predicting the expected macroinvertebrate fauna and assessing the ecological quality of rivers, Ecological Modelling, 160(3): 219-233, 2003.

doi: 10.1016/S0304-3800(02)00255-7

Doley N, Kalita S. A Study on Macroinvertebrate population in relation to some water and soil quality parameters in the wetlands of lower Subansiri basin, Journal of Environmental Research and Development, 8(3A):785-795, 2014.

Edmondson WT. Ward and Whipple's Fresh Water Biology, 2nd Ed. John Wiley and Sons, New York, Environmental Ecology, 9: 995-998, 1993. 
EPA. Lake and reservoir bioassessment and biocriteria, technical guidance document. US Environmental Protection Agency, Washington, D.C., USA, 1998.

George ADI, Abowei JFN, Alfred-Ockiya JF. The Distribution, Abundance and Seasonality of Benthic Macroinvertebrate in Okpoka Creek Sediment, Niger Delta, Nigeria, Research Journal of Applied Sciences Engineering and Technology, 2(1):11-18. 2009.

Ghosh D, Biswas JK. Biomonitoring macrophytes and abundance for rating aquatic health of an oxbow lake ecosystem in Ganga River basin, American Journal of Phytomedicine and Clinical Therapeutics, 3(10): 602-621, 2015d.

Ghosh D, Biswas JK. Fish Fauna Faces Anthropogenic Double Trouble: Erosion of Fish Diversity in Tropical Oxbow Lake of the Ganga River Basin in Eastern India, Journal Biodiversity Endangered Species, 5: 188. 2017 c.

doi: 10.4172/2332-2543.1000188

Ghosh D, Biswas JK. Impact of Jute Retting on Native Fish Diversity and Aquatic Health of Roadside Transitory Water Bodies: An Assessment in Eastern India, Journal of Ecological Engineering, 16(4):14-21, $2015 \mathrm{c}$. doi: 10.12911/22998993/59342

Ghosh D, Biswas JK. Impact of jute retting on phytoplankton diversity and aquatic health: Biomonitoring in a tropical oxbow lake, Journal of Ecological Engineering, 16(5):15-25, 2015e.

doi: 10.12911/22998993/60449

Ghosh D, Biswas JK. Macroinvertebrates' diversity indices: quantitative bio-assessment of ecological health status of an ox-bow lake in eastern India, Journal of Advances in Environmental Health Research, $3(2): 78-90,2015 b$.

Ghosh D, Biswas JK. Rotifera Diversity Indices: Assessment of Aquatic Health of an Oxbow lake ecosystem in West Bengal, International Journal of Current Research, 6(12): 10554-10557, 2014.

Ghosh D, Biswas JK. Zooplankton Diversity Indices: Assessment of an Ox-Bow Lake Ecosystem for Sustainable Management in West Bengal, International Journal of Advanced Biotechnology and Research (IJBR), 6(1): 37-43, 2015a.

Ghosh, D, Biswas, JK. Erosion of Fish Diversity: Ranking Degree of Dangers of unsustainable Fishing gears in a Tropical Oxbow lake in eastern India, IJCBS Research Paper, 3(12): 1-17, 2017 a.

Ghosh, D, Biswas, JK. Fish productivity: Assessing sustainability in a tropical oxbow lake of Nadia district, West Bengal, India, Archives of Agriculture and Environmental Science, 2(1): 6-20, 2017b.

Golterman HL, Clymo RS, Ohnstad MAM. Methods for physical and chemical and analysis of freshwaters. Oxford, Blackwell, IBP Handbook, 1978. 
Gupta S, Narzary R. Aquatic insect community of lake, Phulbarianua in Cachar, Assam, Journal of Environmental Biology, (34): 591-597, 2013.

Ikomi RB, Arimoro FO, Odihirin OK. Composition, distribution and abundance of Macroinvertebrates of the upper reaches of River Ethiope Delta State, Nigeria, The Zoologist, 3: 68-81, 2005.

Imoobe TOT, Ohiozebau E. Pollution status of a tropical forest river, using aquatic insects as indicator, African Journal Ecology, 48: 232-238, 2009.

doi: 10.1111/j.1365-2028.2009.01153.x

Jessup BK, Markowitz A, Stribling J.B, Friedman E, LaBelle K, Dziepak N. Family-Level key to the stream Invertebrates of the Maryland and Surrounding Areas. Maryland Department of Natural Resources: Unite States, 2003.

Kazanci N, Dugel M. An evaluation of the water quality of Yuvarlakçay stream, in the Köyceğiz-Dalyan protected area, SW Turkey, Turkish Journal of Zoology, 24(1): 69-80, 2000.

Kumar PS, Khan AB. The distribution and diversity of benthic macro invertebrate fauna in Pondicherry mangroves, India Aquatic Biosystems, 9: 15, 2013.

doi: 10.1186/2046-9063-9-15

Latha C, Thanga VSG. Macroinvertebrate diversity of Veli and Kadinamkulam lakes, South Kerala, India, Journal of Environmental Biology, 31: 543-547, 2010.

Lenat DR, Penrose DLS, Eagleson KW. Variable effects of Sediment addition on stream benthos, Hydrobiologia, 79: 187-194, 1981.

Merrit RW, Cummins KW. An Introduction to the Aquatic Insects of North America, Kendall/Hunt Publishing Company, Dubuque, Lowa, USA, 1994.

Meyer JL, Strayer DL, Wallace JB, Eggert SL, Helfman GS, Leonard NE. The contribution of headwater streams to biodiversity in river networks, Journal of the American Water Resources Association, 43: 86-103, 2007.

doi: 10.1111/j.1752-1688.2007.00008.x

Nandan SB. Retting of coconut husk-a unique case of water pollution on the South West coast of India, International Journal of Environmental Studies, 52(1-4): 335-355, 1997.

doi: 10.1080/00207239708711110

Obolewski K, Glin’ska-Lewczuk K, Ozgo M, Astel A, Connectivity restoration of floodplain lakes: an assessment based on macroinvertebrate communities, Hydrobiologia, 774: 23-37, 2016

doi: 10.1007/s10750-015-2530-8

Odiete WO. Environmental physiology of animals and pollution. Diversified Resources, Lagos, Nigeria: 220-246, 1999. 
Ogbeibu AE, Oribhabor BJ. Ecological impact of river impoundment using benthic Macroinvertebrates as indicators, Water Research, 36: 2427-2436, 2002.

Olomukoro JO, Dirisu AR. Macroinvertebrate Community and Pollution Tolerance Index in Edion and Omodo Rivers in Derived Savannah Wetlands in Southern Nigeria, Jordan Journal of Biological Sciences, 7(1): 19-24, 2014.

Olomukoro JO, Dirisu AR. Macroinvertebrate Community of a Post Lindane Treated Stream Flowing through a Derived Savannah in Southern Nigeria, Tropical freshwater Biology, 21(1): 67-82, 2012.

doi: $10.4314 / \mathrm{tfb} . v 21$ i1.6

Omoigberale MO, Ogbeibu AE. Environmental Impacts of Oil exploration and production on the invertebrate fauna of Osse River, Southern Nigeria, Research Journal of Environmental Sciences, 4: 101-114, 2010.

doi: 10.3923/rjes.2010.101.114

Ortiz JD, Puig MA. Poind source effects on density, biomass and diversity of benthic Macroinvertebrates in a Mediterranean stream, River Research and Applications, 23: 155-170, 2007.

doi: 10.1002/rra.971

Pennak RW. Fresh invertebrates of the United States; Protozoa to Mollusca. Johan Wily and Sons. INC Pleidae. 535-558, 1989.

Rashid R, Pandit AK. Macroinvertebrates (oligochaetes) as indicators of pollution: A review, Journal of Ecology and the Natural Environment, 6(4): 140-144, 2014.

doi: $10.5897 / \mathrm{JENE} 2014.0443$

Ravera O. Ecological monitoring for water body management. Proceedings of monitoring Tailor made III. International Workshop on Information for Sustainable Water Management: 157-167, 2000.

Richardson JS, Danehy RJ. A synthesis of the ecology of headwater streams and their riparian zones in temperate forests, Forest Science, 53: 131-147, 2007.

Rosenberg, DM, Resh VH. Freshwater Biomonitoring and Benthic Macroinvertebrates. Chapman and Hall, Springer US. 1993.

Selvaraj, GSD. Assessment of Biochemical Oxygen Demand (BOD) in Tropical Aquatic Systems (Modified). CMFRI Special Publication Mangrove ecosystems: A manual for the assessment of biodiversity, 83: 201, 2005.

Sharma C, Rawat JS. Monitoring of aquatic macroinvertebrates as bioindicator for assessing the health of wetlands: A case study in the central Himalayas, India, Ecological Indicators, 9: 118-128, 2009.

doi: 10.1016/j.ecolind.2008.02.004 
Simboura N, Zenetos A. Benthic indicators to use in ecological quality classification of Mediterranean soft bottoms marine ecosystems, including a new biotic index, Mediterranean Marine Science, 3(2):77-111, 2002.

doi: $10.12681 / \mathrm{mms} .249$

Stroud Water Research Centre. Identification Guide to Freshwater Macroinvertebrates 970 Spencer Road Avondale, Pennsylvania 19311, 2015.

Subramanian KA, Shivaramakrishnan KG. Aquatic Insects of India: A field guide, Ashoka Trust for Research in Ecology and Environment (ATREE), 2007.

Subramanian KA, Shivaramakrishnan KG. Damselflies and Dragonflies of Peninsular India- A Field Guide. E-book of the Project Lifescape, Ind. Acad. Sc., \& CES, IISc, Bangalore, India: 118, 2005.

Thorn RSJ, Williams WP. The response of benthic invertebrates to pollution in developing countries: A multi metric system of bioassessment, Freshwater Biology, 37: 671-686, 1997.

doi: 10.1046/j.1365-2427.1997.00181.x

UNEP/EEA. Priority issues in the Mediterranean environment, EEA Report No 5/2005. 2005.

Victor R, Ogbeibu AE. Macrobenthic invertebrates of a stream flowing through farmland in Southern Nigeria, Environmental Pollution Series A, Ecological and Biological, 39(4): 337-349, 1985.

doi: 10.1016/0143-1471(85)90114-X

Water resources department. Laboratory testing procedure for soil and water sample analysis, Directorate of irrigation research and development, Pune, India, 2009.

Wetzel RG, Likens GE. Limnoloical Analyses, Philadelphia: 767, 1991.

Zenetos A, Simboura N. Soft bottom benthic indicators. 36th CIESM Congress Proceedings, Monte Carlo, 24-28 September, 2001: 339. 2001.

Ziglio G, Siligardi M, Flaim G. Biological Monitoring of Rivers: Application and Perspectives. John Wiley \& Sons Ltd: England, 2006. 


\section{Eficiencia del índice de tolerancia a la contaminación (PTI) de macroinvertebrados para detectar contaminación acuática en un lago en herradura en India}

Resumen. Este artículo evalúa la eficiencia del Índice de Tolerancia a la Contaminación basado en macroinvertebrados (PTI), para detectar contaminación acuática en el lago en herradura Chhariganga, India. Los PTIs calculados se compararon con los resultados de un conjunto de parámetros fisicoquímicos del agua y del sedimento, y con una determinación de la diversidad de macroinvertebrados llevada a cabo paralelamente en el mismo lago. Los valores obtenidos del PTI cayeron dentro de un rango (entre 20 y 31) que, de acuerdo con la literatura, es indicativo de ausencia de contaminación orgánica, y que son normalmente reportados para sistemas desprovistos de actividad antropogénica (por ejemplo, actividades contaminantes de enriamiento del yute durante los monzones). Sin embargo, a la luz de los resultados de los parámetros fisicoquímicos de agua y sedimento, y con el soporte de los índices de diversidad de macroinvertebrados usando datos del mismo lago, fue posible concluir que los valores de PTI obtenidos no reflejan el verdadero estado de contaminación del lago en herradura. Como los valores de PTI y los índices de diversidad se contradicen entre sí en detectar la contaminación, se aconseja tomar en consideración ambos parámetros cuando se usen macroinvertebrados para determinar la salud acuática.

Palabras clave: salud acuática; índices de diversidad; macroinvertebrados; contaminación; calidad del agua

\section{Eficiência do Índice de Tolerância a Contaminação (P'TI) de macroinvertebrados para detectar contaminação aquática em um lago em ferradura na Índia}

Resumo. Este artigo avalia a eficiência do Índice de Tolerância a Contaminação baseada em macroinvertebrados (PTI) para detectar contaminação aquática no lago em ferradura Chhariganga, Índia. Neste lago, os PTIs calculados foram comparados com resultados de um conjunto de parâmetros físicoquímicos da água e do sedimento, e com uma determinação da diversidade de macroinvertebrados realizada paralelamente para o mesmo lago. Os valores obtidos para PTI estiveram dentro de um rango (entre 20 e 31) que indica, de acordo a literatura, a ausência de contaminação orgânica, e que é reportado normalmente para sistemas desprovidos de atividade antropogênica (por exemplo, atividades contaminantes de remoção de juta durante as monções). Entretanto, em função dos resultados dos parâmetros físico-químicos de água e sedimentos, e com o suporte dos índices de diversidade de macroinvertebrados usando dados do mesmo lago, foi possível concluir que os valores observados de P'TI não refletem o real estado de contaminação de este lago em ferradura. Como os dados de PTI e os índices de diversidade são contraditórios entre si para detectar a contaminação, se aconselha considerar ambos os parâmetros quando se usem macroinvertebrados para determinar a saúde aquática.

Palavras-chave: saúde aquática; índices de diversidade; macroinvertebrados; contaminacao; qualidade da água 


\section{Dr. Dipankar Ghosh (M.F.Sc., PhD.)}

Obtained his master degree from CIFE (Mumbai, India) and PhD from University of Kalyani (Kalyani, India). Presently, he is employed as an officer in the Department of Fisheries, Government of West Bengal, India. He has published about 20 research papers in international and national journals.

\section{Dr. Jayanta Kumar Biswas (M.Sc., M.Phil., Ph.D.)}

Is presently serving as Associate Professor, Department of Ecological Studies and International Centre for Ecological Engineering, University of Kalyani. He has about 17 years of teaching experience and 21years of research experience in the following areas: ecotechnology; environmental microbiology; ecotoxicology and bioremediation of toxic metal(oid) $\mathrm{s}$; aquatic pollution monitoring and ecoremediation; treatment and bioregenerative reclamation of wastewater. He has published about 90 research papers, mostly in international journals of high repute and about 40 popular science articles in periodicals and magazines. Presently he is associated with many journals in different capacities - as editor-in-chief, member of editorial boards, and as reviewer of many international journals of repute. 